\title{
Correction to: Determination of Dry Wear Properties of Zn-30Al-Cu Bearing Alloys in Terms of Their Copper Content and Working Conditions Including Pressure and Sliding Velocity \\ Hasan Onur Tan (D) and Temel Savaş kan
}

1. Correction to: JMEPEG

https://doi.org/10.1007/s11665-020-04976-7

Readers should note that Eq. 6 and Eq. 9 were published incorrectly.

Equation 6 should read:

$$
\mu=0.35-0.015 C-0.1 v+0.0023 C^{2}-0.017 v^{2}
$$

Equation 9 should read:

$$
\mu=0.3364+0.1347 v-0.0211 p-0.0304 v^{2}+0.0001 p^{2}
$$

Publisher's Note Springer Nature remains neutral with regard to jurisdictional claims in published maps and institutional affiliations.

The original article can be found online at https://oi.org/10.1007/ s11665-020-04976-7.

Hasan Onur Tan, Department of Mechanical Engineering, Giresun University, 28200 Giresun, Turkey; and Temel Savaskan, Department of Mechanical Engineering, Haliç University, 34445 Beyoğlu, Istanbul, Turkey. Contact e-mail: hasan.tan@giresun.edu.tr. 